https://helda.helsinki.fi

\title{
Prevalence and diagnostic outcomes of children with duodenal lesions and negative celiac serology
}

\section{Gustafsson, Ida}

2020-03

Gustafsson , I, Repo , M , Popp , A , Kaukinen , K, Hiltunen , P , Arvola , T, Taavela , J , Vornanen, M , Kivelä , L \& Kurppa , K 2020 , ' Prevalence and diagnostic outcomes of children with duodenal lesions and negative celiac serology ' , Digestive and Liver Disease , vol. 52 , no. 3 , pp. 289-295 . https://doi.org/10.1016/j.dld.2019.11.011

http://hdl.handle.net/10138/325518

https://doi.org/10.1016/j.dld.2019.11.011

publishedVersion

Downloaded from Helda, University of Helsinki institutional repository.

This is an electronic reprint of the original article.

This reprint may differ from the original in pagination and typographic detail.

Please cite the original version. 


\title{
Alimentary Tract
}

\section{Prevalence and diagnostic outcomes of children with duodenal lesions and negative celiac serology ${ }^{\star}$}

\author{
Ida Gustafsson ${ }^{a, 1}$, Marleena Repo ${ }^{a, 1}$, Alina Popp ${ }^{a, b}$, Katri Kaukinen ${ }^{c}$, Pauliina Hiltunen ${ }^{a}$, \\ Taina Arvola ${ }^{\mathrm{d}}$, Juha Taavela ${ }^{\mathrm{e}}$, Martine Vornanen ${ }^{\mathrm{f}}$, Laura Kivelä ${ }^{\mathrm{a}, \mathrm{g}}$, Kalle Kurppa ${ }^{\mathrm{a}, \mathrm{h}, *}$ \\ ${ }^{a}$ Center for Child Health Research, Faculty of Medicine and Health Technology, Tampere University and Department of Pediatrics, Tampere University \\ Hospital, Tampere, Finland \\ b Carol Davila University of Medicine and Pharmacy, National Institute for Mother and Child Health, Bucharest, Romania \\ ${ }^{\mathrm{c}}$ Department of Internal Medicine, Tampere University Hospital and Celiac Disease Research Center, Faculty of Medicine and Health Technology, Tampere \\ University, Tampere, Finland \\ ${ }^{\mathrm{d}}$ Hämeenlinna Central Hospital, Hämeenlinna, Finland and Allergy Centre, Tampere University Hospital, Tampere, Finland \\ e Central Finland Central Hospital, Jyväskylä, Finland \\ f Department of Pathology, Tampere University Hospital, Tampere, Finland \\ ${ }^{g}$ University of Helsinki and Helsinki University Hospital, Children's Hospital, and Pediatric Research Center, Helsinki, Finland \\ ${ }^{\mathrm{h}}$ The University Consortium of Seinäjoki, Seinäjoki, Finland
}

\section{A R T I C L E I N F O}

\section{Article history:}

Received 21 October 2019

Accepted 19 November 2019

Available online 30 December 2019

\section{Keywords:}

Antibodies

Biopsy

Duodenum

Lesion

Seronegative

\begin{abstract}
A B S T R A C T
Background: Celiac disease diagnostics begin by measuring autoantibodies, which may fail to identify seronegative patients. Duodenal lesion in the absence of antibodies is scarcely studied, especially in children.

Aims: To investigate the prevalence and diagnostic outcomes of children with seronegative duodenal lesion in two countries with different disease profiles.

Methods: Medical data, including the results of histology and transglutaminase (tTGab) and endomysium (EmA) antibody measurements were collected from 1172 Finnish and 264 Romanian children with systematic duodenal sampling. Database of 509 Finnish children with celiac disease was examined to identify earlier seronegative patients.

Results: Celiac disease was diagnosed in 307 Finnish and 83 Romanian children in the endoscopy cohorts. No seronegative patients were found among 899 celiac disease patients, although some were only tTGab or EmA positive. Non-celiac duodenal lesion was detected in eight Finnish and 32 Romanian children, their most common diagnoses being inflammatory bowel disease and infections, respectively. Six children with morphological lesion received no diagnosis. None of them developed celiac disease during a follow-up of $3-11$ years.

Conclusion: Pediatric seronegative celiac disease is exceptional in the era of modern autoantibodies. Other reasons for duodenal lesion should therefore be sought, bearing in mind possible differences across countries.
\end{abstract}

(C) 2019 Editrice Gastroenterologica Italiana S.r.l. Published by Elsevier Ltd. All rights reserved.

\section{Introduction}

The estimated prevalence of celiac disease is $1-3 \%$, emphasizing the importance of its practical diagnosis [1]. The traditional

\footnotetext{
$\star$ Prospective part of this study is registered at clinicaltrials.gov; trial identifying number NCT02072590.

* Corresponding author at: Center for Child Health Research, Tampere University, Arvo Ylpön katu 34, Tampere, 33520 Finland.

E-mail address: kalle.kurppa@uta.fi (K. Kurppa).

1 The authors have contributed equally to this article.
}

approach has been identification of duodenal lesion, but the revised European criteria allow non-invasive diagnosis in children [2]. Recent studies support the accuracy of the serology-based guidelines [3,4], but there may be some caveats in the current diagnostic approach. Both European and US diagnostic algorithms [2,5] start from the measurement of tissue transglutaminase antibodies (tTGab), which may fail to identify seronegative patients and leave them exposed to long-term complications. Known reasons for false-negative serology, such as IgA deficiency, can be taken into account during the evaluation [3], but at least adults may have a true seronegative celiac disease [6]. 


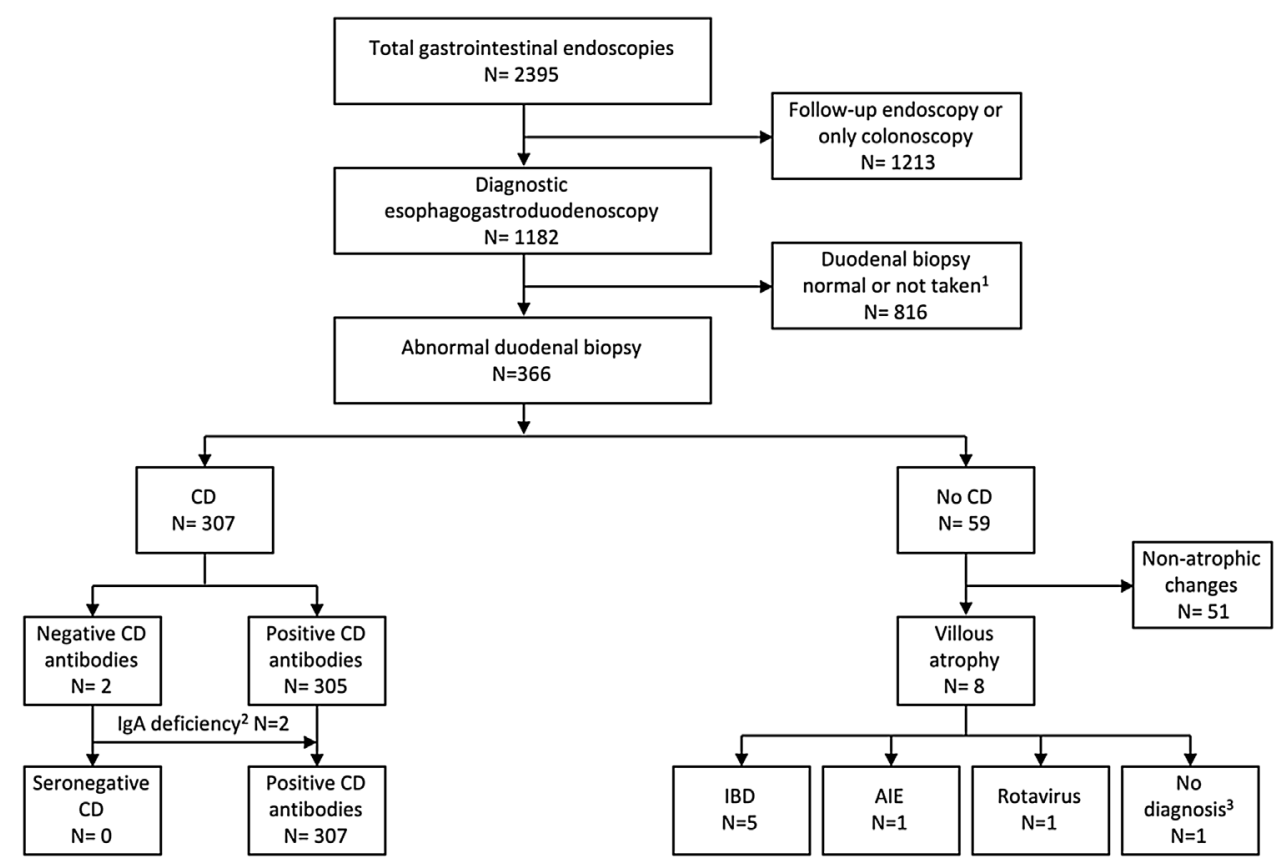

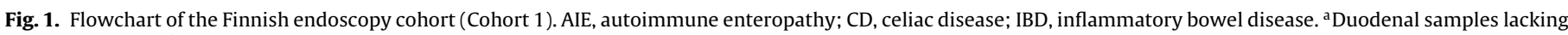
from 10 children; ${ }^{b}$ IgG class autoantibodies positive; ${ }^{\mathrm{c}}$ No diagnosis set during a follow-up of six years.

The differential diagnostics of seronegative duodenal lesions is challenging, as has also been reported in non-celiac conditions [7-9], and the milder the lesion the more unspecific it is [10,11]. Furthermore, early stage celiac disease may be associated with low and/or fluctuating tTGab levels, decreasing the utility of serology in these circumstances [12,13]. An additional challenge is posed by the current approach to also take biopsies from the less specific proximal duodenum [14]. At present, systematic studies on the frequency of seronegative celiac disease and other causes for duodenal lesion in children are lacking. This issue is complicated by the varying practices of endoscopic sampling and the non-standardization of tTGab assays.

Our systematic duodenal sampling in each endoscopy, together with the long tradition of celiac disease research and use of validated histology $[15,16]$, enabled us to explore the outcomes of seronegative lesions. We moreover managed to utilize a corresponding Romanian cohort to compare two countries with disparate disease profiles, and a large Finnish research database to gain historical perspective.

\section{Materials and methods}

\subsection{Patients and study design}

The study was conducted at the Tampere University Hospital and at the National Institute for Mother and Child Health, Bucharest. Three cohorts were included:

1 The Finnish endoscopy cohort (Cohort 1) was composed by collecting the indications and findings of 2395 consecutive gastrointestinal endoscopies carried out 2007-14 in Tampere. After exclusion of repeat endoscopies and cases without duodenal biopsies, the remaining 1172 diagnostic esophagogastroduodenoscopies (EGD) were categorized on the basis of the presence of duodenal pathology (Fig. 1). Children with pathologic findings were further divided into those with and without celiac disease and the latter group further into subjects with and without mor- phological duodenal lesion. From 2012 onwards $>80 \%$ of children with suspected celiac disease have been prospectively enrolled.

2 The Romanian cohort (Cohort 2) was formed by evaluating results of the duodenal histology of 270 consecutive children referred to EGD in 2007-15 from the National Institute for Mother and Child Health. Of these, diagnostic EGD with biopsies was performed on 264 subjects, who were selected for corresponding analyses as in Cohort 1 (Fig. 2). All children since 2012 have been invited to a prospective study.

3 Cohort 3 was extracted from a research database containing information on 1070 Finnish children diagnosed with celiac disease. Patients diagnosed from 2007 onwards overlapped with Cohort 1 and were excluded, as were those with unclear diagnosis, leaving altogether 509 eligible children (Fig. 3).

\subsection{Clinical data}

Demographic data and medical histories were collected from all children. The results of additional investigations, such as laboratory measurements, colonoscopy, magnetic resonance enterography and capsule endoscopy, were also recorded, along with the diagnosis. If no diagnosis was established, relevant follow-up data were collected until May 31, 2018.

\subsection{Celiac disease serology and genetics}

Previously used serum antigliadin antibodies were ignored due to their low specificity [3], as were the infrequently used deamidated gliadin antibodies. Serum antireticulin antibodies (ARA) were measured in the $1980 / 90 \mathrm{~s}$ before being gradually replaced by measurement of endomysium antibodies (EmA). Tests for tTGab become available in 1998 and in the 2000 s tTGab and EmA have been used almost invariably.

In Finnish patients, ARA (Cohort 3) and EmA (Cohorts 1 and 3) have been analyzed by immunofluorescence utilizing rat liver, kidney and stomach tissue (ARA) or human umbilical cord (EmA) as a substrate $[17,18]$. A titre $1: \geq 5$ is considered positive. tTGab (Cohorts 1 and 3 ) have been measured either by conventional ELISA 


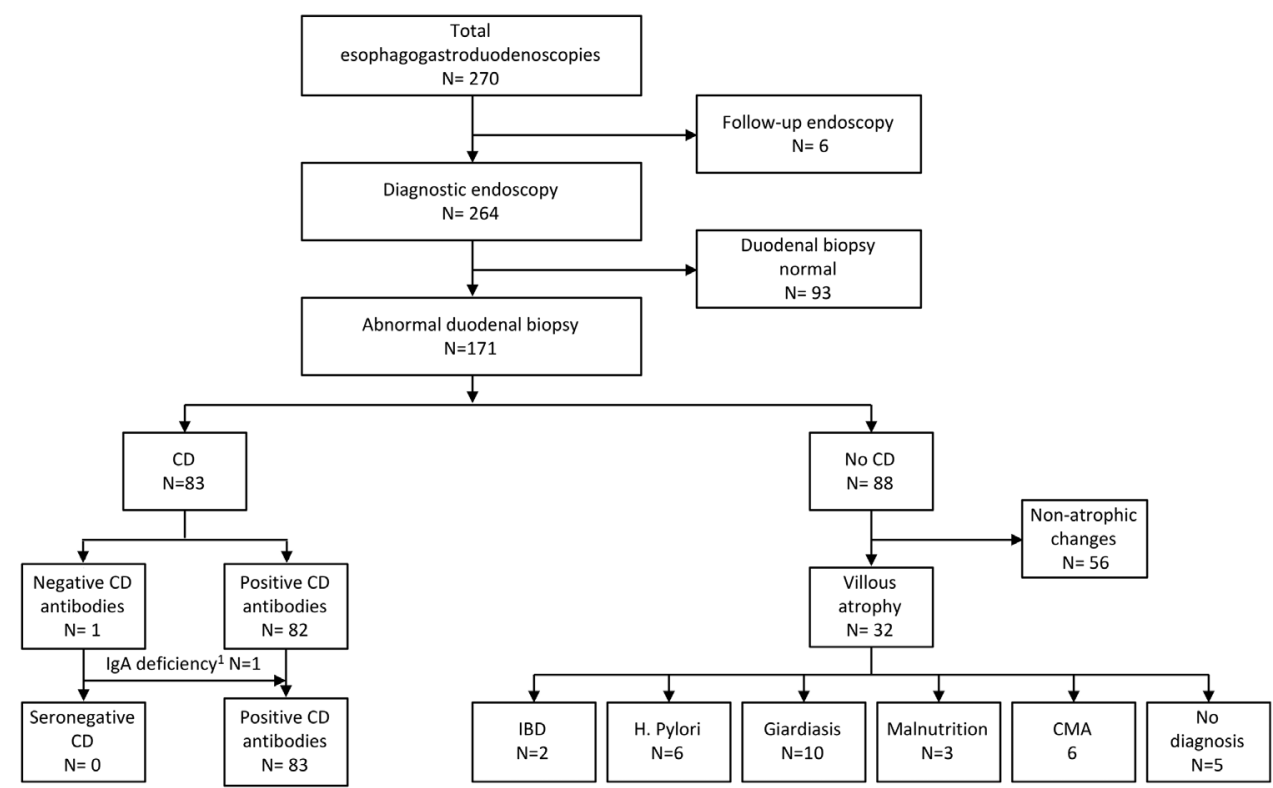

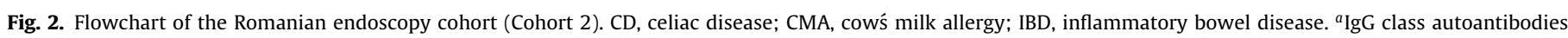
positive.

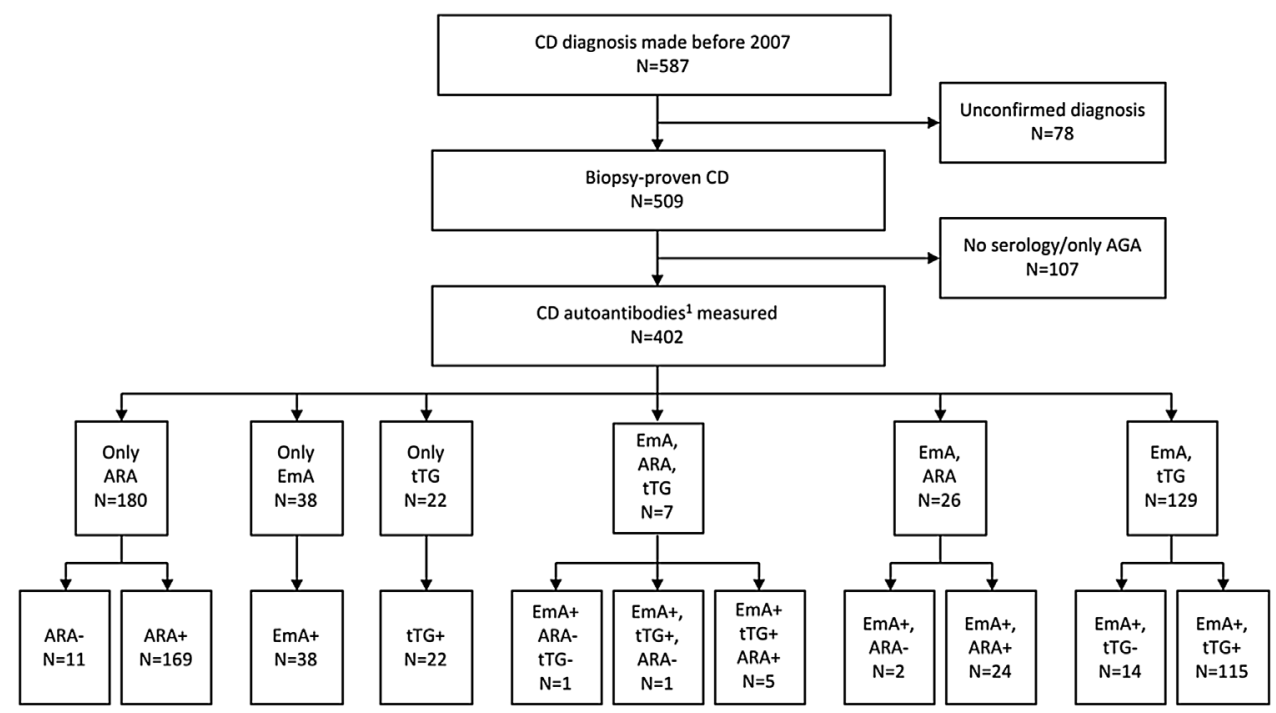

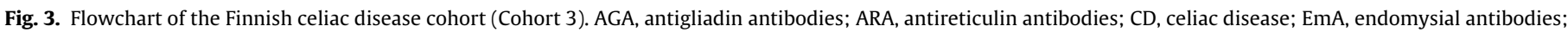
tTG, tissue transglutaminase antibodies. ${ }^{a}$ ARA, EmA and tTG.

(Phadia ${ }^{\circledR}$, Uppsala, Sweden) or, since 2011, by automatized EliA assay $\left(\right.$ Phadia ${ }^{\circledR}$ ) considering values $\geq 7.0 \mathrm{U} / 1$ positive. Some Cohort 3 patients had been tested in the 1990s with other tTGab assays. Romanian patients (Cohort 2) have been tested for EmA by monkey esophagus-based assay (NOVA Lite ${ }^{\circledR}$, INOVA Diagnostics, San Diego, CA, positive $1: \geq 5$ ) and for tTGab either by Phadia ${ }^{\circledR}$ ELISA or by QUANTA Lite ${ }^{\circledR}$ (INOVA; positive $\geq 20 \mathrm{U}$ ).

Seronegative celiac disease denotes constant negativity of autoantibodies in a subject with a biopsy-proven diagnosis. Serological testing at the referral site was also reckoned if performed with equal test. Possible explanations for discrepancies between serology and histology, such as IgA deficiency, reduced gluten consumption and immunosuppression, were scrutinized, as well as was testing with IgG class antibodies in the case of IgA deficiency.

The presence of human leucocyte antigen (HLA) DQ2/DQ8, if analyzed, was recorded. Lack of these haplotypes has a very high negative predictive value for celiac disease [19].

\subsection{Histology}

Almost all duodenal samples in Cohorts 1 and 2 were taken upon EGD, likewise samples after the mid-1980s in Cohort 3. Earlier samples in Cohort 3 and a few samples in Cohort 2 were taken by Watson capsule. In our routine, at least four biopsies are systematically obtained from distal duodenum during EGD and, since 2012, at least two samples also from the bulb [2]. The biopsies are processed and interpreted by pathologists with expertise in the alimentary tract. Only representative and well-orientated biopsy cuttings are accepted for morphometric analyses made from at least three adjacent villous-crypt pairs.

Duodenal abnormalities were categorized into morphological and non-morphological [20]. The more detailed classification of histology, e.g. the frequency and distribution (regionally and along the villous-crypt axis) of intraepithelial lymphocytes (IELs) and other inflammatory cells, and presence of granulomas and 
Table 1

Characteristics of celiac disease patients in the three study cohorts.

\begin{tabular}{|c|c|c|c|}
\hline & Finnish endoscopy cohort & Romanian endoscopy cohort & Finnish research database \\
\hline $\mathrm{N}$ :o of patients & 307 & 83 & 402 \\
\hline Age, median (quartiles),years & $7.4(4.6,11.6)$ & $5.3(3.1,6.4)$ & $8.2(5.0,12.0)$ \\
\hline Girls, \% & 66.4 & 62.7 & 59.2 \\
\hline \multicolumn{4}{|l|}{ Main clinical presentation, \% } \\
\hline Gastrointestinal & 73.3 & 55.6 & 45.7 \\
\hline Extraintestinal $^{\mathrm{a}}$ & 8.3 & 24.1 & 30.4 \\
\hline Screen-detected & 18.4 & 20.4 & 23.9 \\
\hline \multicolumn{4}{|l|}{ At-risk group for celiac disease, $\%$} \\
\hline First-degree relative of a patient & 17.9 & 16.7 & 50.4 \\
\hline Type 1 diabetes & 7.2 & 16.7 & 14.4 \\
\hline Autoimmune thyroidal disease & 0.7 & 3.7 & 9.4 \\
\hline \multicolumn{4}{|l|}{ Severity of the diagnostic lesion, \% } \\
\hline Total villous atrophy & 18.8 & 18.6 & 31.8 \\
\hline Subtotal villous atrophy & 41.4 & 50 & 39.1 \\
\hline Partial villous atrophy & 39.7 & 31.4 & 29.1 \\
\hline
\end{tabular}

a E.g. poor growth, arthritis, neurological symptoms, rash.

abnormal number of plasma cells [8,9], was recorded, as was the categorization of villous atrophy to partial (PVA), subtotal (SVA) and total (TVA). Potential celiac disease was defined as positivity to tTGab/EmA without morphological changes of the duodenal mucosa.

Besides the traditional histology, some of the biopsies from the prospective series were snap-frozen and used in the determination of small-bowel mucosal TG2 targeted IgA deposits [6] and $\gamma \delta+$ IELs. The analysis was conducted using immunohistochemical double staining of the mucosal IgA and tTG with monoclonal antibodies [21].

\subsection{Statistics}

Quantitative variables are presented as number of patients, percentages or medians with upper and lower quartiles. All data were analyzed anonymously using SPSS version 20.0 (IBM, Armonk, NY, USA).

\subsection{Ethical aspects}

The Ethical Committees of the Pirkanmaa Hospital District (Code R11187, 21th Feb 2012) and of the University of Medicine and Pharmacy "Carol Davila" and the National Institute for Mother and Child Health "Alessandrescu-Rusescu" (Code 01242, 12th Sep 2011) approved the prospective studies. All families gave written informed consent. The Department of Pediatrics, Tampere University Hospital and the National Institute for Mother and Child Health approved collection of the retrospective data.

\section{Results}

\subsection{Cohort 1}

The median age of the 1172 children in Cohort 1 was 8.7 years and $54.4 \%$ were girls. The most common diagnoses were celiac disease (Table 1) and inflammatory bowel disease (IBD, $\mathrm{n}=132$ ).

Altogether 366 children had abnormal duodenal histology, including all celiac disease patients (Fig. 1). tTGab was measured from 272 (88.6\%), EmA from 212 (69.1\%), and both from 210 (68.4\%) of those with celiac disease. All of them were positive for either one or both antibodies (Fig. 1). Two EmA positive (titers 1:50 and 1:5; PVA in both) patients had negative tTGab (values $5.1 \mathrm{U} / 1$ and $5.2 \mathrm{U} / \mathrm{l}$ ) and seven EmA negative cases positive tTGab (8.8-21 U/l). Seven of these nine subjects had PVA, one TVA, and one non-specified morphological damage.
Eight seronegative children had morphological duodenal lesion (Fig. 1), none of whom had findings indicative of celiac disease (Table 2). Five children with IBD and the one with autoimmune enteropathy (AIE) responded to their disease-specific treatments and the rotavirus patient had a normal repeat biopsy (Table 2). The non-diagnosed child has not received any diagnosis during a follow-up of six years, the symptoms have diminished and she has remained seronegative.

Fifty-one children had non-morphological duodenal abnormalities (Fig. 1), including 14 with changes only in the bulb. Twelve cases had potential celiac disease, five of whom subsequently received a diagnosis. No other cases with celiac disease have so far been diagnosed.

\subsection{Cohort 2}

The median age of the 264 Romanian children was 6.3 years and $51.1 \%$ were girls. Altogether 171 children had abnormal duodenal histology (Fig. 2). Celiac disease was diagnosed in 83 children (Table 1), of whom all were seropositive, including one with $\operatorname{IgA}$ deficiency (Fig. 2). Of the celiac patients, tTGab was measured from 82 (98.8\%), EmA from 77 (92.8\%), and both from 76 (91.6\%). None of the EmA positive patients had negative tTGab, while one EmA negative case had positive tTG-ab. The latter child had normal villi but crypt hyperplasia (Marsh 2) diagnostic for pediatric celiac disease [6], as well as positive IgA deposits and HLA DQ2.

Thirty-two children had seronegative duodenal lesion, their most frequent diagnoses being giardiasis, H. Pylori, and cowś milk allergy (Fig. 2). HLA and immunohistochemistry were obtained from six children participating in the prospective series. All had negative IgA deposits and two negative HLA DQ2/8 (Table 3). None of the other 26 cases had signs of celiac disease initially or during a follow-up of 2-15 years, and the majority improved during their disease-specific treatments (Supplementary Table).

Fifty-six children had non-morphological duodenal lesion (Fig. 2), including six with changes only in the bulb. Twenty-seven of these subjects had potential celiac disease and three of them have later developed celiac disease.

\subsection{Cohort 3}

The autoantibodies were measured from 402 patients (Fig. 3, Table 1). The last ARA testing was done in 2004 and the first EmA and tTGab testings in 1994 and 1998 respectively. ARA was negative in 14 and tTGab in 15 untreated children, but whenever EmA was concurrently measured it was positive (Fig. 3). Median antibody values of the 15 tTGab negative EmA positive cases were $5.6 \mathrm{U} / 1$ 
Table 2

Main diagnostic findings and selected follow-up data of the Finnish children presenting with duodenal atrophy without celiac disease.

\begin{tabular}{|c|c|c|c|c|c|c|c|c|}
\hline $\mathrm{N}: \mathrm{O}$ & Age, yr & Sex & $\begin{array}{l}\text { Clinical } \\
\text { presentation }\end{array}$ & $\begin{array}{l}\text { tTGab, } \\
\mathrm{U} / \mathrm{l}^{\mathrm{a}}\end{array}$ & EmA, titer & $\begin{array}{l}\text { Duodenal } \\
\text { histology }\end{array}$ & Other relevant findings & Diagnosis \\
\hline 1. & 4.8 & M & $\begin{array}{l}\text { Bloody stools, } \\
\text { anemia } \\
\text { abdominal pain }\end{array}$ & ND & $1:<5$ & $\begin{array}{l}\text { PVA, } \\
\text { inflammation } \\
\text { in lamina } \\
\text { propria; later } \\
\text { biopsy normal }\end{array}$ & $\begin{array}{l}\text { Increased ESR, ANCA and } \\
\text { F-calprotectin; pancolitis with } \\
\text { granulomas; positive response to } \\
\text { IBD treatment }\end{array}$ & Crohn's disease \\
\hline 2. & 11.7 & $\mathrm{~F}$ & $\begin{array}{l}\text { Diarrhea, } \\
\text { abdominal } \\
\text { pain, poor } \\
\text { growth }\end{array}$ & 0.3 & ND & $\begin{array}{l}\text { PVA, } \\
\text { inflammation } \\
\text { in lamina } \\
\text { propria; later } \\
\text { biopsy } \\
\text { inflammation }\end{array}$ & $\begin{array}{l}\text { Increased ESR, ASCA and } \\
\text { F-calprotectin; proctitis and } \\
\text { granulomas; positive response to } \\
\text { IBD treatment }\end{array}$ & Crohn's disease \\
\hline 3. & 14.8 & M & $\begin{array}{l}\text { Tiredness, } \\
\text { anemia, } \\
\text { diarrhea, poor } \\
\text { growth }\end{array}$ & 0.5 & $1:<5$ & $\begin{array}{l}\text { PVA, epithelial } \\
\text { inflammation; } \\
\text { later biopsy } \\
\text { inflammation }\end{array}$ & $\begin{array}{l}\text { Increased ESR, ASCA and } \\
\text { F-calprotectin, fistulae and } \\
\text { strictures; negative HLA DQ2/8; } \\
\text { positive response to ileal resection }\end{array}$ & Crohn's disease \\
\hline 4. & 15.2 & $\mathrm{~F}$ & $\begin{array}{l}\text { Anemia } \\
\text { abdominal } \\
\text { pain, poor } \\
\text { growth }\end{array}$ & 0.4 & ND & $\begin{array}{l}\text { SVA, } \\
\text { inflammation } \\
\text { in lamina } \\
\text { propria and } \\
\text { epithelium }\end{array}$ & $\begin{array}{l}\text { Increased ESR and F-calprotectin; } \\
\text { pancolitis and ulcerations in ileum; } \\
\text { positive response to IBD treatment }\end{array}$ & Crohn's disease \\
\hline 5. & 9.9 & M & $\begin{array}{l}\text { Anemia, bloody } \\
\text { stools }\end{array}$ & 0.2 & $1:<5$ & $\begin{array}{l}\text { PVA, } \\
\text { inflammation } \\
\text { in lamina } \\
\text { propria and } \\
\text { epithelium; } \\
\text { later biopsy } \\
\text { normal }\end{array}$ & $\begin{array}{l}\text { Increased ESR and ANCA; moderate } \\
\text { pancolitis; positive response to IBD } \\
\text { treatment }\end{array}$ & $\begin{array}{l}\text { Ulcerative } \\
\text { colitis }\end{array}$ \\
\hline 6. & 0.3 & M & $\begin{array}{l}\text { Diarrhea, poor } \\
\text { growth }\end{array}$ & $\mathrm{ND}^{\mathrm{b}}$ & $\mathrm{ND}^{\mathrm{b}}$ & $\begin{array}{l}\text { TVA, } \\
\text { inflammation } \\
\text { in lamina } \\
\text { propria and } \\
\text { epithelium, } \\
\text { crypt apoptosis }\end{array}$ & $\begin{array}{l}\text { Negative anti-enterocyte } \\
\text { antibodies; normal colonoscopy; } \\
\text { positive response to tacrolimus }\end{array}$ & $\begin{array}{l}\text { Autoimmune } \\
\text { enteropathy }\end{array}$ \\
\hline 7. & 1.8 & M & $\begin{array}{l}\text { Abdominal } \\
\text { pain, anemia }\end{array}$ & 0.1 & $1:<5$ & $\begin{array}{l}\text { PVA, } \\
\text { inflammation } \\
\text { in lamina } \\
\text { propria and } \\
\text { epithelium; } \\
\text { later biopsy } \\
\text { normal }\end{array}$ & $\begin{array}{l}\text { Normal F-calprotectin and rectal } \\
\text { biopsy; severe reflux; one month } \\
\text { later positive stool rotavirus } \\
\text { antigen }\end{array}$ & $\begin{array}{l}\text { Rotavirus } \\
\text { infection }\end{array}$ \\
\hline 8. & 4.1 & $\mathrm{~F}$ & $\begin{array}{l}\text { Abdominal } \\
\text { pain, } \\
\text { hematemesis, } \\
\text { constipation }\end{array}$ & 1.2 & $1:<5$ & $\begin{array}{l}\text { PVA, no } \\
\text { inflammation; } \\
\text { later biopsy } \\
\text { PVA in bulb }\end{array}$ & $\begin{array}{l}\text { Celiac disease serology repeatedly } \\
\text { negative. No diagnosis during } \\
\text { long-term follow-up }\end{array}$ & No \\
\hline
\end{tabular}

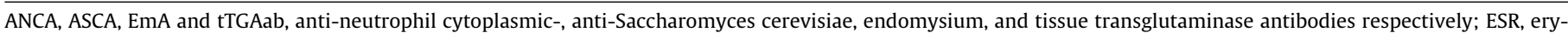

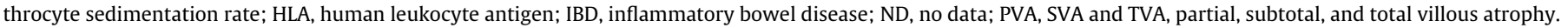

a Celikey ${ }^{\oplus}$. cut off $<5.0 \mathrm{U} / \mathrm{l}$.

b He had never consumed gluten.

(range 2.0-6.5 U/1). Twelve (80\%) of them had PVA, one had SVA, and two had TVA.

\subsection{Other results and factors possibly affecting histologic or serologic findings}

All celiac disease patients participating in the prospective series had positive HLA DQ2/8 and IgA deposits. None of the children with non-celiac duodenal abnormalities in Cohorts 1 and 2 were regularly taking medications associated with such changes or had reduced gluten consumption.

\section{Discussion}

We found seronegative celiac disease to be exceptional in children. The result is almost unbiased, since the children in Cohorts 1 and 2 had undergone systematic duodenal sampling. There may have been seronegative patients who were not biopsied due to mild symptoms, but early seropositivity seems to be more common [22]. Almost all cases with seronegative duodenal lesion were readily explained by another condition. Likewise, no seronegative children were found in the historical database, although several tTGab negative EmA positive cases suggest the use of EmA to target the endoscopies. However, if present, one would still expect to detect some seronegative patients among children biopsied on a clinical basis, particularly as such cases were found in the era of less sensitive ARA. In contrast to our results, seronegative celiac disease is frequent in adults, even if inconsistent definitions hamper comparisons $[6,7,23,24]$. This indicates age-related differences in serology, for example due to increasing avidity of the antibodies to the intestinal production site observed in our previous study [6]. Likewise, Vivas et al. [25] reported an inverse relationship between tTGab levels and age at diagnosis.

There has been lack of studies on pediatric seronegative celiac disease. Such cases have been reported when evaluating the performance of serological tests [2], but these situations are affected by the intended nature of the assay. A good test is sensitive but also specific enough, which usually necessitates a compromise. Due to its intrinsic properties, test for EmA is specific but rather impractical $[5,26]$. Sensitivity may also be lower compared to tTGab [5], but 
Table 3

Diagnostic findings and follow-up data of Romanian children participating in prospective study and presenting with duodenal atrophy without celiac disease.

\begin{tabular}{|c|c|c|c|c|c|c|c|c|}
\hline N:O & Age, yr & Sex & $\begin{array}{l}\text { Clinical } \\
\text { presentation }\end{array}$ & $\begin{array}{l}\text { tTGab, } \\
\mathrm{U} / \mathrm{I}^{\mathrm{a}}\end{array}$ & EmA, titer & Duodenal histology & Other relevant findings & Diagnosis \\
\hline 1. & 3.8 & $\mathrm{~F}$ & $\begin{array}{l}\text { At-risk group } \\
\text { screening }^{\mathrm{b}}\end{array}$ & $<3.0$ & $1:<5$ & $\begin{array}{l}\text { PVA, inflammation in } \\
\text { lamina propria. Later } \\
\text { biopsy only inflammation. }\end{array}$ & $\begin{array}{l}\text { Negative mucosal IgA } \\
\text { deposits }\end{array}$ & No \\
\hline 2. & 14.6 & M & $\begin{array}{l}\text { Dyspepsia, } \\
\text { vomiting } \\
\text { headache, } \\
\text { reflux }\end{array}$ & $<3.0$ & $1:<5$ & $\begin{array}{l}\text { SVA, inflammation in } \\
\text { lamina propria and } \\
\text { epithelium, later biopsy } \\
\text { normal }\end{array}$ & $\begin{array}{l}\text { Gastritis, negative mucosal } \\
\text { IgA deposits }\end{array}$ & Gastritis \\
\hline 3. & 10.5 & M & $\begin{array}{l}\text { Weight loss, } \\
\text { nausea, } \\
\text { vomiting, } \\
\text { anemia, } \\
\text { vitamin D } \\
\text { deficiency }\end{array}$ & $<3.0$ & $1:<5$ & $\begin{array}{l}\text { PVA, inflammation in } \\
\text { lamina propria }\end{array}$ & $\begin{array}{l}\text { Negative mucosal IgA } \\
\text { deposits, clinical } \\
\text { improvement on treatment }\end{array}$ & Ascariasis \\
\hline 4. & 5 & $\mathrm{~F}$ & $\begin{array}{l}\text { Anemia, failure } \\
\text { to thrive, } \\
\text { abdominal pain }\end{array}$ & $<3.0$ & $1:<5$ & $\begin{array}{l}\text { PVA, inflammation in } \\
\text { lamina propria, giardiasis. }\end{array}$ & $\begin{array}{l}\text { Negative mucosal IgA } \\
\text { deposits, clinical } \\
\text { improvement on treatment }\end{array}$ & Giardiasis \\
\hline 5. & 6.2 & $\mathrm{~F}$ & $\begin{array}{l}\text { Abdominal } \\
\text { pain, poor } \\
\text { teeth, anemia, } \\
\text { reflux }\end{array}$ & $<3.0$ & $1:<5$ & $\begin{array}{l}\text { PVA, inflammation in } \\
\text { lamina propria and } \\
\text { epithelium }\end{array}$ & $\begin{array}{l}\text { Gastritis, negative } \\
\text { HLADQ2/DQ8 and mucosal } \\
\text { IgA deposits, clinical } \\
\text { improvement on treatment }\end{array}$ & Gastritis \\
\hline 6. & 4.3 & $\mathrm{~F}$ & $\begin{array}{l}\text { Anemia, } \\
\text { vitamin D } \\
\text { deficiency }\end{array}$ & $<3.0$ & $1:<5$ & $\begin{array}{l}\text { SVA, no inflammation, later } \\
\text { biopsy normal }\end{array}$ & $\begin{array}{l}\text { Negative mucosal IgA } \\
\text { deposits, clinical } \\
\text { improvement during } \\
\text { follow-up }\end{array}$ & Malnutrition \\
\hline
\end{tabular}

HLA, human leukocyte antigen; PVA, SVA and TVA, partial, subtotal, and total villous atrophy.

a Celikey $^{\circledR}$, cut off $<3.0 \mathrm{U} / \mathrm{l}$.

b Previous type 1 diabetes, family history of celiac disease.

this depends on the cut-off. For example, we found several tTGab negative EmA positive patients, but if a lower threshold of $5.0 \mathrm{U} / 1$ were applied, almost all of these would turn positive. Setting an optimal limit is hampered by the non-standardization of the tTGab tests [3]. Physicians should therefore know the basic characteristics of the assay used and perhaps utilize EmA in borderline values, as these patients would be missed if the current guidelines were applied. Other types of antibody assays $[27,28]$ and HLA determination might also be utilized. If endoscopy is performed, sophisticated methods, such as immunohistochemistry, might prove helpful.

Non-celiac duodenal lesion was quite common, particularly in Romania. Although concurrent celiac disease is theoretically possible, in most cases this is unlikely as the children either responded to specific treatment or recovered without intervention. Duodenal histopathology, even if unspecific, was also usually inconsistent with celiac disease. Furthermore, making celiac disease unlikely, subjects who participated to the prospective series had negative IgA deposits and/or HLA DQ2/8 [6,29,30], although specificity of the former remains debated [31]. Among most of the other children receiving no diagnosis, celiac disease was again meticulously ruled out during the initial investigations. Furthermore, the cases followed up either remained repeatedly seronegative or showed spontaneous histological improvement, and none have developed celiac disease so far.

Causes of non-celiac duodenal lesion varied markedly between the sites, being predominantly IBD in Finland and infections in Romania. This likely reflects country differences in the ongoing shift from infectious to immune mediated diseases [32], although further studies on this subject are needed. In any case, the result showed that many conditions observed in adults may also occur in children, including IBD, infections, immunodeficiencies, and malnutrition [24,33]. Differential diagnostics includes clinical presentation, endoscopic findings throughout the alimentary track and the results of other studies [33-35]. Histologic features that can help to target further investigations are e.g. granulomas, reduced plasma cells and increased density of villous tip IELs [8,9,36,37]. Our results show that the local disease profile should also be acknowledged. Pitfalls in histology (Figure 4) and serology [2] should be kept in mind and, if any suspicion remains, even a treatment trial could be utilized [7].

Milder duodenal abnormalities were also frequent in seronegative children. The main causes and country differences across countries in these followed mostly that with the morphologic changes. Complicating the differential diagnostics, children with early stage celiac disease may exhibit borderline tTGab values or intermittent seronegativity [11-13,22]. Supporting this, almost all subjects with disconcordancies in seropositivity had only PVA. In general, however, the autoantibodies seem to appear early in the disease course. [38] Accordingly, none of the seronegative children with minor duodenal histopathology has developed celiac disease during the long-term follow-up, this also being rare in the few earlier studies on this issue [10,11].

Our main strengths were the large cohorts of children from two disparate countries and the systematic duodenal sampling. Utilization of validated histomorphometry and immunohistochemistry improved the differential diagnostics, although the latter was not available in retrospective series. We also managed to collect comprehensive follow-up data right up until the present day. The main limitation was the retrospective design before 2012, with the resulting unsystematic use of serology and possible selective execution of endoscopies in the older series. Also, subjects with unexplained duodenal lesion were not systemically re-biopsied as there is a high threshold for the procedure in children.

To conclude, truly seronegative celiac disease seems to be exceptional in children. Other reasons for duodenal lesion should thus be meticulously excluded, bearing in mind possible differences across countries, before setting such a diagnosis. It is helpful to be aware of the basic characteristics of the serological assays used and, if feasible, to apply advanced diagnostic methodology in borderline cases. 


\section{Grant support}

The study was supported by the Competitive State Research Financing of the Expert Area of Tampere University Hospital and the Foundation for Pediatric Research.

\section{Conflict of interest}

None declared.

\section{List of abbreviations}

AIE, autoimmune enteropathy; ARA, antireticulin antibody; EGD, esophagogastroduodenoscopy; EmA, endomysium antibody; HLA, human leucocyte antigen; IBD, inflammatory bowel disease; IEL, intraepithelial lymphocyte; PVA, partial villous atrophy; SVA, subtotal villous atrophy; tTGab, tissue transglutaminase antibody; TVA, total villous atrophy.

\section{Appendix A. Supplementary data}

Supplementary material related to this article can be found, in the online version, at doi:https://doi.org/10.1016/j.dld.2019.11. 011.

\section{References}

[1] Myléus A, Ivarsson A, Webb C, Danielsson L, Hernell O, Högberg L, et al. Celiac disease revealed in $3 \%$ of Swedish 12 -year-olds born during an epidemic. J Pediatr Gastroenterol Nutr 2009;49:170-6.

[2] Husby S, Koletzko S, Korponay-Szabó IR, Kurppa K, Mearin ML, Ribes-Koninckx C, et al. European Society for Pediatric Gastroenterology, Hepatology and Nutrition guidelines for diagnosing coeliac disease 2019. J Pediatr Gastroenterol Nutr 2019, http://dx.doi.org/10.1097/MPG.0000000000002497.

[3] Werkstetter KJ, Korponay-Szabó IR, Popp A, Villanacci V, Salemme M, Heilig G, et al. Accuracy of diagnosis of celiac disease without biopsies in clinical practice. Gastroenterology 2017;153:924-35.

[4] Wolf J, Petroff D, Richter T, Auth MKH, Uhlig HH, Laass MW, et al. Validation of antibody-based strategies for diagnosis of pediatric celiac disease without biopsy. Gastroenterology 2017;153:410-9.

[5] Hill ID, Dirks MH, Liptak GS, Colletti RB, Fasano A, Guandalini S, et al. Guideline for the diagnosis and treatment of celiac disease in children: recommendations of the North American Society for Pediatric Gastroenterology, Hepatology and Nutrition. J Pediatr Gastroenterol Nutr 2005;40:1-19.

[6] Salmi TT, Collin P, Korponay-Szabó IR, Laurila K, Partanen J, Huhtala H, et al. Endomysial antibody-negative coeliac disease: clinical characteristics and intestinal autoantibody deposits. Gut 2006;55:1746-53.

[7] Aziz I, Peerally MF, Barnes JH, Kandasamy V, Whiteley JC, Partridge D, et al. The clinical and phenotypical assessment of seronegative villous atrophy; a prospective UK centre experience evaluating 200 adult cases over a 15-year period (2000-2015). Gut 2017;66:1563-72.

[8] Kamboj A, Oxentenko A. Clinical and histologic mimickers of celiac disease. Clin Transl Gastroenterol 2017;8:e114

[9] Owen DR, Owen DA. Celiac disease and other causes of duodenitis. Arch Pathol Lab Med 2018;142:35-43.

[10] Lähdeaho ML, Kaukinen K, Collin P, Ruuska T, Partanen J, Haapala AM, et al. Celiac disease: from inflammation to atrophy: a long-term follow-up study. J Pediatr Gastroenterol Nutr 2005;41:44-8.

[11] Shmidt E, Smyrk T, Faubion W, Oxentenko AS. Duodenal intraepithelial lymphocytosis with normal villous architecture in pediatric patients: mayo Clinic experience, 2000-2009. J Pediatr Gastroenterol Nutr 2013;56:51-5

[12] Simell S, Hoppu S, Hekkala A, Simell T, Ståhlberg MR, Viander M, et al. Fate of five celiac disease-associated antibodies during normal diet in genetically risk children observed from birth in a natural history study. Am J Gastroenterol 2007;102:2026-35.
[13] Auricchio R, Tosco A, Piccolo E, Galatola M, Izzo V, Maglio M, et al. Potential celiac children: 9-year follow-up on a gluten-containing diet. Am J Gastroenterol 2014;109:913-21.

[14] Taavela J, Popp A, Korponay-Szabó IR, Ene A, Vornanen M, Saavalainen P, et al. A prospective study on the usefulness of duodenal bulb biopsies in celiac disease diagnosis in children: urging caution. Am J Gastroenterol 2016;111:124-33.

[15] Kivelä L, Kaukinen K, Lähdeaho ML, Huhtala H, Ashorn M, Ruuska T, et al. Presentation of celiac disease in Finnish children is no longer changing: a 50-year perspective. J Pediatr 2015;167:1109-15.

[16] Taavela J, Koskinen O, Huhtala H, Lähdeaho ML, Popp A, Laurila K, et al. Validation of morphometric analyses of small-intestinal biopsy readouts in celiac disease. PLoS One 2013;8:e76163.

[17] Ladinser B, Rossipal E, Pittchieler K. Endomysium antibodies in coeliac disease: an improved method. Gut 1994;35:776-8.

[18] Unsworth DJ. Serological diagnosis of gluten sensitive enteropathy. J Clin Pathol 1996;49:704-11.

[19] Kaukinen K, Partanen J, Mäki M, Collin P. HLA-DQ typing in the diagnosis of celiac disease. Am J Gastro 2002:97:695-9.

[20] Rostami K, Marsh MN, Johnson MW, Mohaghegh H, Heal C, Holmes G, et al ROC-king onwards: intraepithelial lymphocyte counts, distribution \& role in coeliac disease mucosal interpretation. Gut 2017;66:2080-6.

[21] Järvinen TT, Kaukinen K, Laurila K, Kyrönpalo S, Rasmussen M, Mäki M, et al. Intraepithelial lymphocytes in celiac disease. Am J Gastro 2003;98:1132-7.

[22] Agardh D, Lee HS, Kurppa K, Simell V, Aronsson CA, Jörneus O, et al. Clinical features of celiac disease: a prospective birth cohort. Pediatrics 2015;135:627-34

[23] Abrams JA, Diamond B, Rotterdam H, Green PH. Seronegative celiac disease: increased prevalence with lesser degrees of villous atrophy. Dig Dis Sc 2004;49:546-50.

[24] Volta U, Gaio G, Boschetti E, Giancola F, Rhoden KJ, Ruggeri E, et al. Seronegative celiac disease: shedding light on an obscure clinical entity. Dig Liv Dis 2016;48:1018-22.

[25] Vivas S, Ruiz de Morales JG, Riestra S, Arias L, Fuentes D, Alvarez N, et al. Duodenal biopsy may be avoided when high transglutaminase antibody titers are present. World J Gastroenterol 2009;15:4775-80.

[26] Korponay-Szabo IR, Dahlbom I, Laurila K, Koskinen S, Woolley N, Partanen J, et al. Elevation of IgG antibodies against tissue transglutaminase as a diagnostic tool for coeliac disease in selective IgA deficiency. Gut 2003;52:1567-71.

[27] Lindfors K, Koskinen O, Kurppa K, Laurila K, Collin P, Haimila K, et al. Serodiagnostic assays for celiac disease based on the open or closed conformation of the autoantigen, transglutaminase 2. J Clin Immunol 2011;31:436-42.

[28] Kurppa K, Lindfors K, Collin P, Saavalainen P, Partanen J, Haimila K, et al. Antibodies against deamidated gliadin peptides in early-stage celiac disease. J Clin Gastroenterol 2011;45:673-8.

[29] Koskinen O, Collin P, Lindfors K, Laurila K, Mäki M, Kaukinen K, et al. Usefulness of small-bowel mucosal transglutaminase-2 specific autoantibody deposits in the diagnosis and follow-up of celiac disease. J Clin Gastroenterol 2010;44:483-8.

[30] Karell K, Louka AS, Moodie SJ, Ascher H, Clot F, Greco L, et al. HLA types in celiac disease patients not carrying the DQA1*05-DQB1*02 (DQ2) heterodimer: results from the European Genetics Cluster on Celiac Disease. Hum Immunol 2013;64:469-77

[31] Maglio M, Ziberna F, Aitoro R, Discepolo V, Lania G, Bassi V, et al. Intestinal production of anti-tissue transglutaminase 2 antibodies in patients with diagnosis other than celiac disease. Nutrients 2017;9:10.

[32] Vegh Z, Burisch J, Pedersen N, Kaimakliotis I, Duricova D, Bortlik M, et al. Incidence and initial disease course of inflammatory bowel diseases in 2011 in Europe and Australia: results of the 2011 ECCO-EpiCom inception cohort. J Crohns Colitis 2014;8:1506-15.

[33] Jansson-Knodell C, Hujoel I, Rubio-Tapia A, Murray JA. Not all that flattens villi is celiac disease: a review of enteropathies. Mayo Clin Proc 2018:93:509-17.

[34] Hardee S, Alper A, Pashankar DS, Morotti RA. Histopathology of duodenal mucosal lesions in pediatric patients with inflammatory bowel disease: statistical analysis to identify distinctive features. Pediatr Dev Pathol 2014:17:450-4.

[35] Schiepatti A, Sanders D, Biagi F. Seronegative coeliac disease: clearing the diagnostic dilemma. Curr Opin Gastroenterol 2018;34:154-8.

[36] Tobin JM, Sinha B, Ramani P, Saleh AR, Murphy MS. Upper gastrointestinal mucosal disease in pediatric Crohn disease and ulcerative colitis: a blinded, controlled study. J Pediatr Gastroenterol Nutr 2001;32:443-8.

[37] Järvinen TT, Collin P, Rasmussen M, Kyrönpalo S, Mäki M, Partanen J, et al. Villous tip intraepithelial lymphocytes as markers of early-stage coeliac disease. Scand J Gastroenterol 2004;39:428-33.

[38] Hagopian W, Lee HS, Liu E, She JX, Ziegler AG, Lernmark Å, et al. Cooccurrence of type 1 diabetes and celiac disease autoimmunity. Pediatrics 2017; 140:e20171305. 